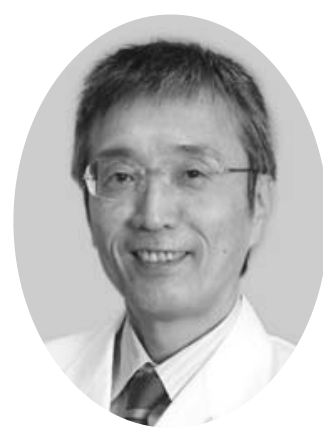

\title{
老人病研究所の近況報告 医学研究を楽しむ
}

\author{
南 史朗
}

日本医科大学老人病研究所所長 大学院医学研究科/老人病研究所 教授 (加齢科学系生体機能制御学)

1954 年に設立された老人病研究所が，1990 年に現在の武蔵小杉に移転して 21 年になる.その間に, メディカル サイエンスの世界は大いに発展を遂げ, 分子生物学, ゲノム科学, 再生医療と, 社会の関心を集めつつ進歩してき た. 老人病研究所は, 老人病を研究する場として生まれたが, 昨今では老化は一つの普遍的な生命現象として研究 されるようになった. 現在の本研究所での活動は, 代謝研究と癌研究の二つの柱をもって進められている. 最近, 本研究所のオリジナル論文としてネイチャー誌に二報が揭載された。一つは水素研究で, 一つは癌抑制遺伝子研究 である. 本稿では, 老人病研究所の研究活動の一部をご紹介したいと思う.

生化学部門 (細胞生物学分野) では, 様々な機能をもち, 多くの病気や老化現象に関わっているミトコンドリア を重視しながら, 病気の原因と対策を開発しょうとする. ミトコンドリアから発せられる電子と酸素が結びつくこ とで生まれる活性酸素は, その強い酸化力で生活習慣病や老化の原因となることは今や広く知られている. 活性酸 素のうち遺伝子を破壞する「ヒドロキシルラジカル」などの問題になる活性酸素だけを選択的に排除する抗酸化物 質が「水素」であることを発見し，その水素の医療応用への可能性を示した (Ohsawa I, et al.: Nature Medicine 2007; 13:688).これまでに, モデル動物を用いて, 水素水による認知機能低下の改善, 抗がん剂シスプラチンによ る腎障害の改善, パーキンソン病の改善など, 活性酸素種のスカベンジャーとしての働き以外にも水素分子の機能 があることが推定された.

免疫部門（遺伝子制御学分野）では，癌抑制遺伝子 p53 を中心に研究が進められている. p53 は代表的な癌抑制 因子であり, 研究目的は,「どのようにして癌遺伝子が活性化した細胞が, p53によって選択的に排除されるか」を 明らかにすること, すなわち, p53によるアポトーシスや細胞老化の誘導機構, および癌遺伝子による p53 活性化 機構と p 53 による転写誘導機構を明らかにすることにある. これらの解析を行うなかで, p53 が NF-kB の制御を 介してグルコース代謝を調節していること, p53 の機能がなくなるとグルコース代謝が上昇してエネルギーの産生 が増えること，このことが癌化に重要であることを初めて示した (Kawauchi K, et al:: Nature Cell Biology 2008; 10: 611).これは, 癌化の分子機構を考える上で極めて重要であり, 新しい癌の治療法の開発につながると考えられる. 
疫学部門（生体機能制御学分野）では，ホルモン・生理活性物質を対象として生理学的研究を行っている. 糖・ タンパク代謝において重要なインスリン・IGF-I の細胞内シグナル伝達系の変動がどのように生体の恒常性維持に 寄与しているのかを解析している，そして，低タンパク質栄養状態の動物では，タンパク質代謝が低下するために エネルギー消費量も低下するが，余剩となった糖を主に肝臓が取り込んで脂質として蓄積する仕組みが稼働してい ることを示した（Toyoshima Y, et al:: J Mol Endocrinol 2010; 45:329)。このような臟器間の連携において, 脂肪 細胞のホルモン分泌臟器としての病態への役割にも焦点をあてて研究をしている．肥満関連炎症性疾患の病態, 特 に激状動脈硬化や急性冠症候群といった血管壁での炎症病態の進展において重要な役割を果たすマクロファージに 対するアディポネクチンの抗炎症分子メカニズムを解明し，治療法の開発につなげることを目指している.

病理部門（分子細胞構造学分野）では，血管形成機序およびケロイド発生機序について分子レベルでの解析を行 っている，血管は大動脈から毛細血管まで多様な口径サイズをもつ，その形成機構の違いを明らかにし，治療に必 要な口径サイズの血管を薬剂によって誘導する新規治療法の開発を目指している．また，武蔵小杉病院形成外科と 共同で無瘏痕創傷を目的としたケロイドの発症機構の解析を行っている. マイクロアレイ解析の結果から, IL-6 を 中心としたシグナルがケロイド発生に媣く関与していることを明らかにしており, 無瘷痕創傷を目的にその治療を 目指した研究にも着手している.

このように，質の高い研究成果をあげるとともに，研究成果の実際の医療への還元こそが，老人病研究所設立当 初からの変わら媢標である. 病院内にある研究所として, 医療の現場からの必要性を肌で感じながら研究を行い, 単純な個人の興味から始まった研究であっても，いつかは医療に貢献できるように願っている.

(受付：2011 年 1 月 28 日) 